\title{
Design of Microcontroller Based Injector Test Kit
}

\section{Rancang Bangun Alat Uji Injektor Berbasis Mikrokontroler}

\author{
Rahmat Hidayat ${ }^{*}$, Dwi Sudarno Putra ${ }^{1}$, Irma Yulia Basri ${ }^{1}$
}

\begin{abstract}
Automotive technology is growing very rapidly. one of the conventional fuel intake systems to the injection system. where is the fuel intake by the ECU based on engine conditions detected by electronic sensors. The injection will work optimally if the injector that is working is not blocked or has problems, the injector determines the smoothness of the injection system. If the injector's performance is less than optimal, the injection system is not optimal and the engine performance is disrupted. To maintain the injector before working optimally, routine cleaning of the injector is carried out, the problem is the scarcity of the injector test equipment encountered in the field because of the high cost of the equipment, therefore the researchers innovated the design of the injector test equipment using EFI fuel system capable of handling problematic injector problems and the scarcity of this tool in the field.
\end{abstract}

\section{Keywords}

injector, electronic fuel injection, EFI, innovation

\begin{abstract}
Abstrak
Teknologi otomotif berkembang sangat pesat. salah satunya perubahan sistem pemasukan bahan bakar konvensional ke sistem injeksi. dimana pemasukan bahan bakar diatur oleh ECU berdasarkan kondisi mesin yang dideteksi oleh sensor-sensor elektronik. Injeksi tersebut akan bekerja optimal jika injektor yang bekerja tidak tersumbat atau bermasalah, injektor menjadi penentu lancarnya pengabutan sistem injeksi. jika kinerja injektor yang kurang optimal, membuat sistem injeksi tidak maksimal dan kinerja mesin terganggu. Untuk menjaga injektor supaya bekerja optimal maka dilakukan perawatan rutin pembersihan injektor, kendalanya adalah langkanya alat uji injektor yang ditemui dilapangan karna mahalnya alat tersebut, oleh karna itu peneliti melakukan inovasi rancang bangun alat uji injektor dengan mengadopsi sistem bahan bakar EFI yang mampu mengatasi permasalahan injektor bermasalah dan langkanya alat ini dilapangan.
\end{abstract}

\section{Kata Kunci}

injektor, electronic fuel injection EFI, inovasi.

1 Jurusan Teknik Otomotif, Universitas Negeri Padang

JIn. Prof. Dr. Hamka Air Tawar Padang 25131 Indonesia

*rahmathidayat95222@gmail.com

Submitted : December 27, 2018. Accepted : January 08, 2019. Published : January 15, 2019. 


\section{PENDAHULUAN}

Teknologi otomotif dunia berkembang sangat pesat. Mulai dari desain interior, exterior, kontruksi mesin, bahkan sampai ke sistem kelistrikan dan sistim pengapian yang telah mengalami perkembangan yang signifikan dari tahun ke tahun. Salah satu sistem pengapian mobil ialah platina yang berkembang menggunakan CDI (Capasitor Discharge Ignition). dan ECU (Electronic Control Unit) yang lebih pintar dan mampu menyesuaikan dengan pengaturan yang diperlukan aktuator pada mesin sesuai dengan karakter pengguna sehingga didapatkan performa maksimal. pesatnya pertumbuhan kendaraan mobil di Indonesia mengakibatkan peningkatan penggunaan bahan bakar minyak disektor transportasi. selain itu dari gas buang yang mengandung polutan juga menigkat dan mempertinggi kadar pencemaran udara.

Pada 10 Maret 2017 yang lalu, Menteri Lingkungan Hidup telah menandatangangi Peraturan Mentri Lingkungan Hidup dan Kehutanan No. P. 20 /MENLHK /SETJEN /KUM.1/3 /2017 tentang Baku Mutu Gas Buang Kendaraan Bermotor Tipe Baru kategori M, N, dan 0 atau yang lebih dikenal dengan Standar Emisi Euro IV. Dengan berlakunya peraturan ini, maka segala fasilitas uji layak jalan kendaraan bermotor roda dua dan roda empat wajib menggunakan metode uji Euro 4 dan juga industri otomotif dalam negeri untuk menyiapkan infrastruktur produksi dan teknologi perawatan mesin yang sesuai.

Salahsatu metode yang sering digunakan oleh mekanik dan bengkel saat ini adalah metode manual, yaitu membersihkan kotoran dalam saluran injektor dengan kompresor dan cairan pembersih, saat melakukan service injektor pada mobil pelanggan. Hal tersebut dapat dilihat pada gambar 1 berikut.

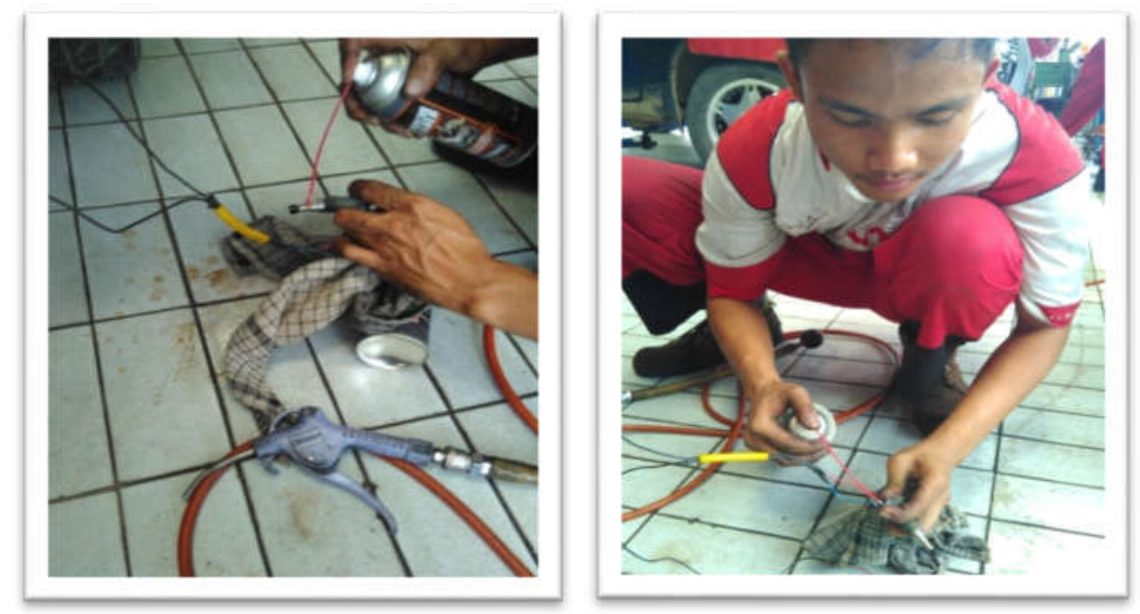

Gambar 1. Membersihkan Injektor dengan Metode Manual [1]

Fakta ini dilator belakangi oleh mahalnya alat pembersih injektor, sehingga tidak semua bengkel dan tempat servis memilikinya. Cara manual tersebut memiliki dua kekurangan yakni (1) akan merusak injektor jika proses dilakukan dengan tekanan angin yang besar dan (2) proses hanya sebatas untuk membersihkan saja tidak ada proses pengujian keseragaman injeksi sehingga tidak diketahui secara pasti apakah injektor masih bagus atau tidak. Jika dua hal tersebut terjadi maka umur pakai injektor akan lebih pendek.

Melihat kenyataan bahwa injector cleaner sangat penting dalam proses perawatan kendaraan tetapi dari segi harga yang ada masih terbilang mahal. Peralatan ini sangat penting bagi proses perawatan sebuah mesin mobil karena keakuratan dalam penginjeksian bahan bakar sangat diperlukan dalam proses pembakaran yang sempurna dan gas buang yang dihasilkan juga sesuai dengan ambang batas yang telah ditetapkan. Sehingga pada penelitian 
ini penulis telah berkontribusi untuk membuat sebuah alat pembersih dan sekaligus alat uji injektor mobil yang lebih murah dengan memanfaatkan teknologi mikrokontroler sebagai pusat pengendalian kerjanya.

Mesin adalah alat mekanik atau elektrik yang mengirim atau mengubah energi untuk melakukan atau alat membantu mempermudah pekerjaan manusia, sistem pengontrolan modern merupakan satu sistem pada kendaraan yang berfungsi untuk menghasilkan tenaga secara efisien, beberapa parameter dikontrol baik oleh sistem mekanis maupun elektronik, Hal hal yang mempengaruhi kemampuan mesin adalah volume langkah total, perbandingan kompresi, efisiensi volumetrik dan pengisian, efisiensi panas. Pengontrolan mesin pada kendaraan modern dilakukan secara elektronik, sistem yang di mesin misalnya sistem pencampuran bahan bakar, sistem pengapian, dan sistem emisi. Sistem pencampuran bahan bakar disebut Electronic Fuel Injection (EFI). Jadi sistem pengontrolan mesin modern merupakan singkronisasi antara sistem mekanis dengan elektronik untuk meningkatkan efisiensi dari mesin.

\section{Electronic Fuel Injection}

Injektor adalah salah satu bagian dari sistim bahan bakar yang akan mengabutkan bahan bakar agar terjadi proses pencampuran yang homogen antara udara dan bahan bakar[2]"injektor adalah komponen yang berfungsi menyemprotkan bahan bakar kedalam ruang bahan bakar"[3]. Jadi Injektor adalah salah satu bagian dari sistem bahan bakar yang akan mengabutkan bahan bakar agar terjadi proses percampuran yang homogen antara udara dan bahan bakar. Injektor dilengkapi dengan plunger yang akan membuka dan menutup saluran bahan bakar dan kerja plunger dikontrol oleh solenoid yang mendapat instruksi dari engine ECU. Bahan bakar akan keluar lebih gemuk ketika plunger tertahan lebih panjang atau sebaliknya. Pengaturan campuran bahan bakar gemuk, kurus, dan saat kapan mulai diinjeksikan tergantung dari sinyal yang dikirim oleh engine ECU.

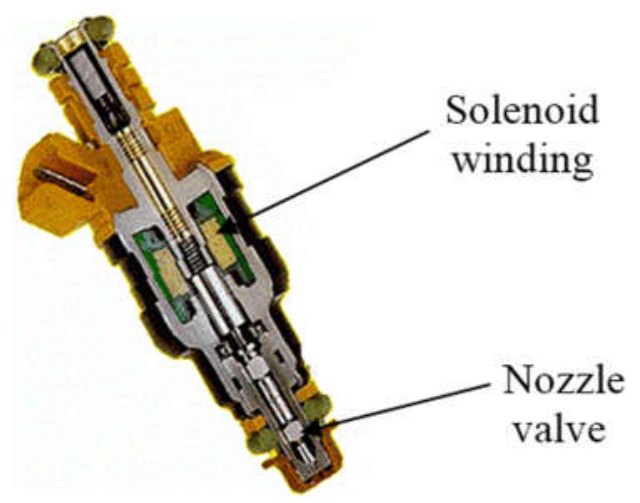

Gambar 2. Injektor

\section{Karakteristik injektor yang baik}

Bentuk pengabutan injektor harus memiliki bentuk yang baik hal ini berpengaruh terhadap kinerja dari sebuah kendaraan yang menggunakan sistem bahan bakar EFI. "Tekanan bahan bakar pada injektor diatur oleh presure regulator, perubahan tekanan bahan bakar akibat injeksi bahan bakar dan variasi perubahan vacum manifold mengakibatkan jumlah bahan bakar yang di injeksikan berubah [4]."Pola penyemprotan injektor di pengaruhi oleh tekanan bahan bakar. Menentukan sebuah injektor masih baik digunakan dapat dilakukan dengan cara membandingkan pola penyemprotan injektor dengan standarnya. 


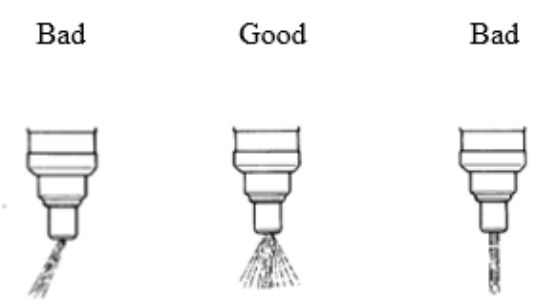

Gambar 3. Sudut Penyeprotan Injektor [5]

\section{Mikrokontroler}

Mikrokontroler adalah sebuah chip yang berfungsi sebagai pengontrol rangkaian elektronik dan umunya dapat menyimpan program didalam umumnya terdiri dari CPU, memori, I/O tertentu dan unit pendukung seperti Analog-to-Digital Converter yang sudah terintegrasi di dalamnya.dengan kata lain mikrokontroler adalah versi mini atau mikro dari sebuah komputer karena mikrokontroler sudah mengandung beberapa periferal yang langsung bisa di mamfaatkan, misalnya port paralel, port serial, komparator, konversi digital ke analog konversi analog ke digital dan sebagainya hannya menggunakan sistem minimun yang tidak rumit atau kompleks. Beberapa peneliti di dunia otomotif menggunakan mikrokontroler untuk mengembangkan alat alat embedded yang bersifat inovatif [10][11]. Mikrokontroler yang relative mudah untk dipelajari adalah Arduino.

\section{Arduino Mega 2560}

Arduino Mega 2560 adalah sebuah papan mikrokontroler berbasis Atmega 2560, mempunyai 54 pin digital input/output (dimana 14 pin dapat digunakan sebagai keluaran PWM), 16 pin input analog, 2 UARTs (Hardware serial ports), sebuah crystal oscillator $16 \mathrm{MHz}$, sebuah penghubung USB, sebuah colokan listrik, ICSP header, dan tombol kembali. Setiap isi dari Arduino Mega 2560 membutuhkan dukungan mikrokontroler, koneksi mudah antara Arduino mega 2560 ke komputer dengan sebuah kabel USB atau daya dengan AC ke DC adaptor atau baterai untuk memulai. Arduino mega cocok sebagai rancangan pelindung untuk Arduino Deumilanove atau Diecimila.

Berdasarkan penelitian, bahwa salah satu Perawatan Sistem Injeksi Bensin adalah Pengujian dan Pembersihan Injektor , faktor faktor yang menjadi penyebab kerusakan injektor pada mobil elektronik fuel injection (EFI) adalah Tersumbat 7.0\%, Abrasi (Terkikis) 4.2\%, Bocor 3.5\%, Selenoid Mati 2.1\%, Tersumbat Sebagian 17.6\%, Tahanan/ Resistensi solenoid turun/rendah 8.4\%, Kotor 31.7\%, Pola Semprotan tidak baik 25.4\%, dan penyimpangan Pola semprotan[6]

\section{METODE PENELITIAN}

Jenis metode yang digunakan dalam penelitian ini adalah metode penelitian pengembangan (research and development). metode penelitian pengembangan secara sederhana dapat didefinisikan sebagai metode penelitian yang secara sengaja, sistematis, bertujuan/diarahkan untuk mencari temukan, merumuskan memperbaiki, mengembangkan, menghasilkan, menguji keefektifan produk, model, metode/ strategi/cara, jasa. Prosedur tertentu yang lebih unggul, baru, efektif, efisien, produktif dan bermakna[7]. Penelitian pengembangan adalah metode penelitian yang digunakan untuk menghasilkan produk tertentu dan menguji keefektifan produk tersebut[8]

Objek Penelitian merupakan sasaran atau objek yang dijadikan pokok pembicaraan dalam penelitian[9]. Adapun yang menjadi objek penelitian dalam penelitian ini ialah Alat Uji injektor yang menggunakan sistem Mikrokontroler. penelitian ini adalah penelitian pengembangan level 3, meneliti dan menguji untuk mengembangkan produk yang telah ada. Objek penelitian 
ini adalah alat uji injektor berbasis mikrokontroler, penelitian dilaksanakan dalam beberapa tahap, yaitu (1) Potensi dan Masalah, (2) Mendesain Produk, (3) Validasi Desain, (4) Revisi Desain, (5) Pembuatan Produk, (6) Uji Coba Produk, (7) Revisi Produk, (8) Uji Coba Pemakai, (9) Revisi produk. Data yang di kumpulkan ada 3 yaitu data observasi melalui praktek lapangan indusri, Data yang dikumpulkan sewaktu seminar Proposal, sedangkan data untuk tes adalah hasil uji coba pemakaian di labor.

Data hasil uji labor diolah secara statistik. untuk menganalisa keseluruhan data yang diperoleh dan mengungkapkan hasil pengukuran pada masing-masing injektor cleaner maka dilakukan analisa data untuk membandingkan nilai rata-rata dari masing-masing pengujian dan disajikan dalam grafik

\section{HASIL DAN PEMBAHASAN}

Rangkaian diagram elektronik alat uji injektor disusun berdasar pada gambar 4. Dan alat uji ini telah berhasil dibuat seperti terlihat pada gambar 5. Alat ini terdiri dari beberapa bagian bagian komponen ada bagian proses, Input dan output atau aktuator dari alat ini, bagian prosesnya atau sentral pengontrol alat ini adalah mikrokontroler merupakan otak dari alat ini yang berfungsi untuk mengolah input masukan frekuensi (pembukaan solenoid injektor dan motor DC) kemudian diolah dengan chip sehingga nantinya dapat memberikan signal pada output mikrokontroler. Bagian dan komponen yang ada pada alat yang dihasilkan seperti pada tabel 1.

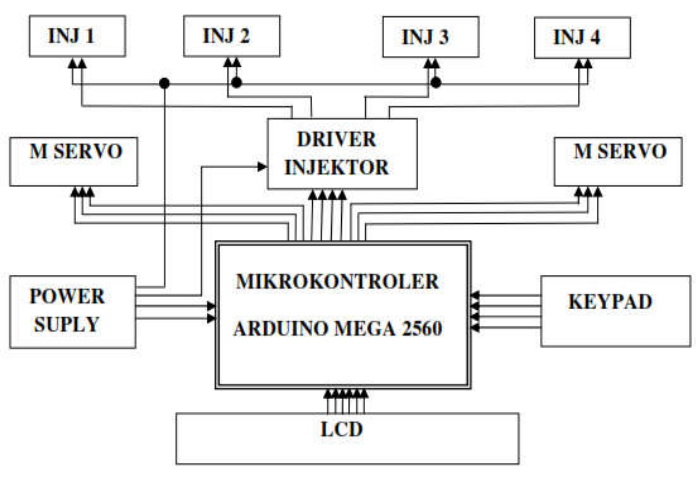

Gambar 4. Desain Elektronika Alat Uji Injektor

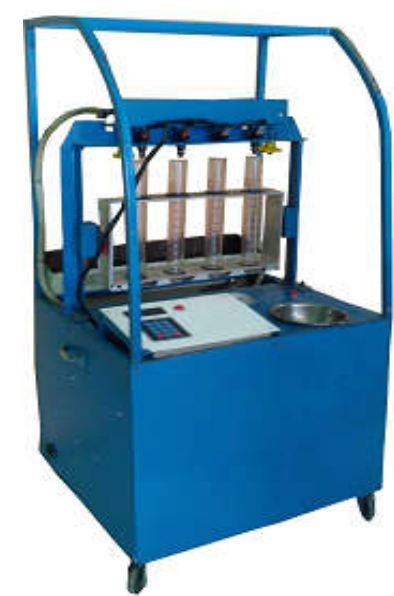

Gambar 5. Hasil Produk Rancangan Alat Uji Injektor Berbasis Mikrokontroler 
Tabel 1. Bagian dan komponen alat uji injektor

\begin{tabular}{|c|c|c|c|}
\hline Kode & $\begin{array}{l}\text { Nama } \\
\text { Komponen }\end{array}$ & Fungsi & Gambar Rancangan \\
\hline A & Rangka & $\begin{array}{l}\text { Sebagai } \\
\text { penopang dan } \\
\text { dudukan } \\
\text { komponen } \\
\text { alat }\end{array}$ & \\
\hline B & Gelas Ukur & $\begin{array}{l}\text { Sebagai alat } \\
\text { ukur } \\
\text { keseragaman } \\
\text { Volume } \\
\text { Injeksi }\end{array}$ & \\
\hline $\mathrm{C}$ & $\begin{array}{l}\text { Sistem } \\
\text { Tekanan }\end{array}$ & $\begin{array}{l}\text { Pensuply } \\
\text { tekanan } \\
\text { pembersih }\end{array}$ & \\
\hline $\mathrm{D}$ & Casing Body & $\begin{array}{l}\text { Menutupi } \\
\text { bagian alat, } \\
\text { rangka dan } \\
\text { sistem } \\
\text { tekanan. }\end{array}$ & \\
\hline $\mathrm{E}$ & $\begin{array}{l}\text { Dudukan } \\
\text { Injektor dan } \\
\text { Saluran } \\
\text { Buang }\end{array}$ & $\begin{array}{l}\text { Sebagai } \\
\text { tempat letak } \\
\text { injektor yang } \\
\text { akan di } \\
\text { bersihkan dan } \\
\text { saluran } \\
\text { pengembali } \\
\text { cairan }\end{array}$ & \\
\hline
\end{tabular}

Perancangan Program menggunakan bahasa c, software yang digunakan adalah driver dan IDE, IDE arduino adalah software yang sangat canggih ditulis dengan menggunakan java, IDE arduino terdiri dari editor program yaitu sebuah window yang memungkinkan menulis dan mengedit program dalam bahasa processing, compiler yaitu sebuah modul yang mengubah kode program menjadi kode biner, selanjutnya adalah uploader yaitu sebuah modul yang memuat kode biner dari komputer ke dalam memory di dalam papan Arduino.

Dasar dari algoritma alat uji injektor ini adalah persamaan matematika yang menentukan lamanya injektor bekerja dan lamanya waktu injeksi. Algoritma pada alat ini menggunakan dasar kerja sistim bahan bakar EFI 4 Tak, dimana informasi yang diperoleh oleh sensor putaran, 
sensor posisi throttle, sensor posisi camshaft, sensor temperatur cairan pendingin, sensor heated oxygen, dan sensor lainnya untuk selanjutnya informasi tersebut dikelola oleh ECU untuk mengatur jumlah bahan bakar yang diinjeksikan. Prinsip kerja injektor on (inj on) tergantung informasi dari sensor tersebut. semakin cepat putaran yang dideteksi sensor dan semakin tinggi beban mesin maka kebutuhan bahan bakar juga semakin banyak sehingga injektor on akan menginjeksikan bahan bakar lebih banyak. Khusus untuk alat ini jumlah bahan bakar yang diinjeksikan hannya ditentukan dari informasi putaran per menit dan mengabaikan informasi dari sensor sensor yang lain. Kemudian informasi putaran ini dicari waktu lamanya injeksi dengan algoritma tabel dibawah ini, sebagai penentu lamanya Inj on dan Inj off.

Tabel 2. Dasar Algoritma Pemograman Alat

\begin{tabular}{|c|l|c|c|c|}
\hline Rpm & inj/s & time inj (ms) & inj on & inj off \\
\hline $\begin{array}{c}\text { Input } \\
\text { manual }\end{array}$ & $\left(\frac{R p m}{2}\right) /$ & $=\frac{1000}{(i n j / s)}$ & $\frac{m s}{4}=$ Inj on & ms - inj on \\
\hline $60 s$ & & & \\
\hline
\end{tabular}

Tabel 2. menjelaskan lamanya injektor bekerja, bahwa injektor tersebut bekerja dalam satuan mili detik. Dalam proses kerjanya alat ini injektor diatur lamanya waktu aktif dan lamanya waku berhentinya yang dikenal dengan istilah Inj on dan Inj of. Untuk mendapatkan on dan off waktu kerjanya pengguna hannya perlu memasukan data RPM, dari data RPM ini dicari waktu injeksi perdetiknya dengan membagi dua data RPM karna pada motor 4 tak dikenal dua kali putaran poros engkol hannya satu injeksi bahan bakar atau satu kali pembakaran, selanjutnya untuk mendapatkan waktu injeksi per detiknya dibagi 60 detik, setelah dapat waktu injeksi per detiknya maka selanjutnya dicari injeksi per mili detik dengan membagi 1000 maka didapat waktu kerjanya injektor (MS) setelah didapat waktu kerjanya maka dicari waktu kapan injektor on dan kapan off dengan cara membagi per empat untuk injektor on dan untuk injektor off, MS dikurangi Inj On, misalnya pada RPM 1200 secara otomatis dengan algoritma yang sudah dibuat, injeksi perdetiknya adalah 10 injeksi, sehingga didapatkan inj on 25 ms dan inj off 75 ms. Pada alat ini pengguna memasukkan beberapa Rpm, dan lamanya injektor akan bekerja kemudian secara otomatis algoritma dari alat ini menentukan MS dan jumlah injeksinya. Setelah program alat ini dibuat maka dilakukan penginstalan kedalam miktrokontroler dengan menggunakan kabel USB. Berdasarkan rancangan program diatas menghasilkan Spesifikasi pada tabel 3.

Tabel 3. Spesifikasi alat uji injektor

\begin{tabular}{|l|l|}
\hline Spesifikasi & Keterangan \\
\hline Tegangan Masuk & 220 volt \\
\hline Tegangan Kerja & 12 volt dan 5 volt \\
\hline Mikrokontroler & Arduino mega 2560 \\
\hline Indikator Tampilan & LCD \\
\hline Keypad & Keypad $4 \times 4$ \\
\hline Servo & HS-311 \\
\hline Max Presure & 40,2 PSI \\
\hline Dimension Unit & $40 \mathrm{~cm} 40 \mathrm{~cm} \times 80 \mathrm{~cm}$ \\
\hline Massa & $10 \mathrm{~kg}$ \\
\hline Tank size & 3 liter \\
\hline
\end{tabular}


Kemudian untuk memudahkan pengoperasian alat, digunakan layer LCD dengan tampilan seperti terlihat pada gambar 6 . Uji coba produk menghasilkan cara penggunaan produk atau mengoperasikan produk seperti saat dihidupkan akan keluar tampilan seperti "injector cleaner starting..." dan setelah itu keluar keterangan "injector cleaner Teknik Otomotif " ketika sudah ada perintah untuk memasukkan RPM dan Timer baru pengguna bisa menginputkan jumlah RPM dan TIMER sesuai dengan kebutuhan kerja alat ini, hasil input RPM dan TIMER akan diproses mikrokontroler untuk dieksekusi oleh injektor berupa ritme penginjeksian.
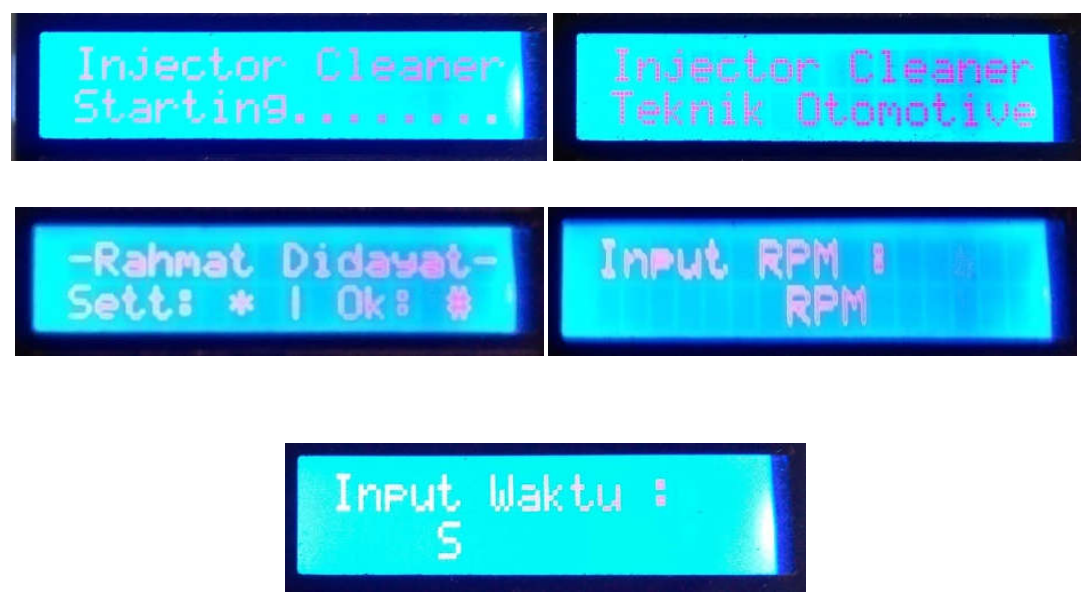

Gambar 6. Tampilan Indikator LCD Alat Uji Injektor.

Uji coba dilakukan dengan cara menguji sinkronisasi dari perangkat keras (hardware) alat uji injektor dengan perangkat lunaknya (software), dalam artian apakah program dari perangkat lunak dapat dijalankan pada perangkat kerasnya. Jika pengujian ini berhasil maka dapat dilangsungkan dengan uji pemakaian, sekaligus membandingkan dengan alat sebelumnya.

Berdasarkan analisa data didapatkan keseragaman penyemprotan dari injektor 1 dan injektor 2 pada Alat uji injektor berbasis mikrokontroler dan Model 271021. dalam buku manual batas maksimal dari keseragaman penyemprotan antar injektor adalah kurang dari $9 \%$.

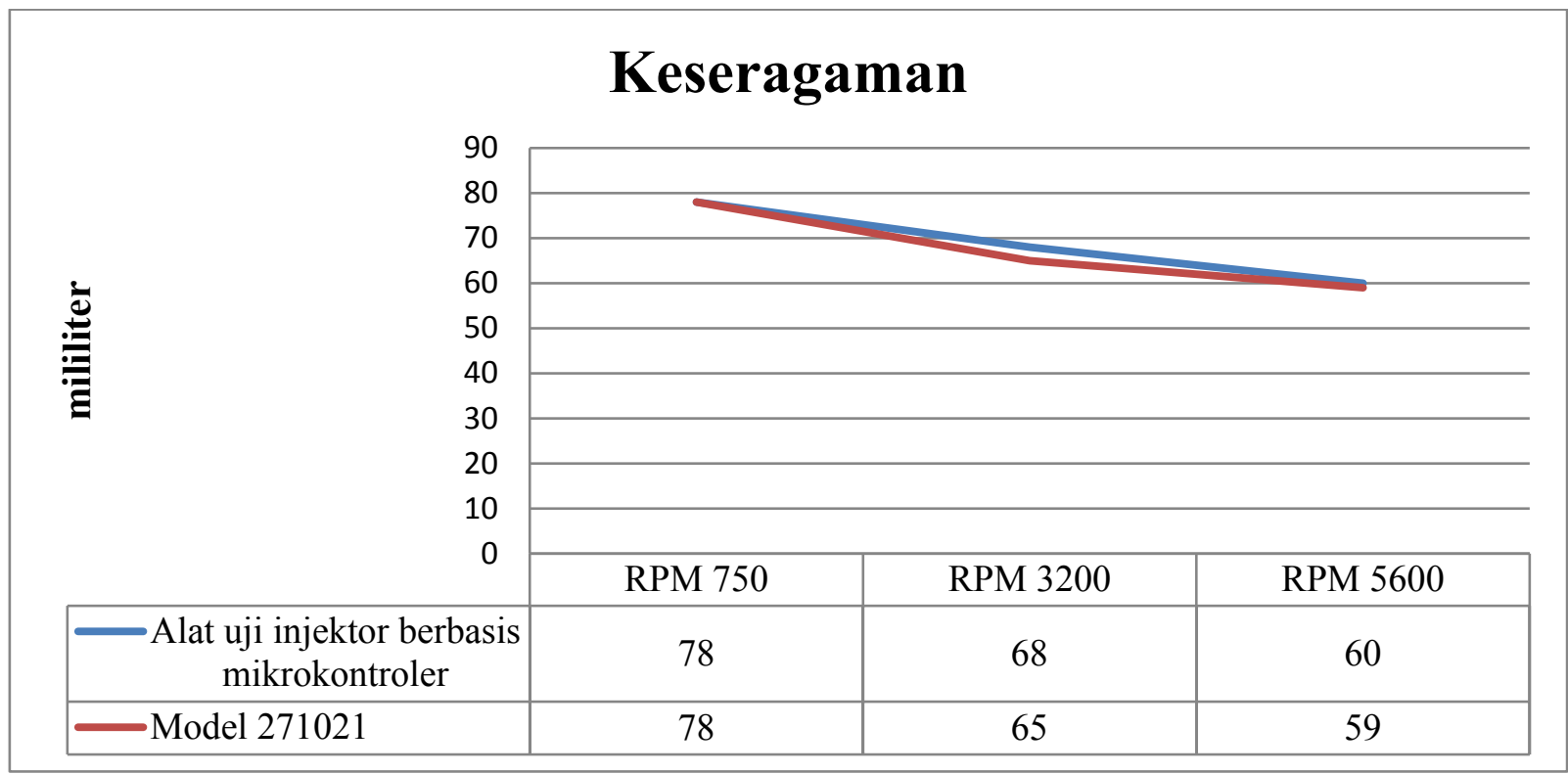

Gambar 7. Grafik Keseragaman Penyemprotan. 
Pada RPM 750 dengan menggunakan alat Alat uji injektor berbasis mikrokontroler adalah 78 ml sedangkan dengan RPM sama pada alat Model 271021 mean yang didapatkan sebesar $78 \mathrm{ml}$. Mean pada RPM 3200 dengan menggunakan alat Alat uji injektor berbasis mikrokontroler adalah $\mathbf{6 8} \mathbf{~ m l}$ sedangkan dengan RPM sama pada alat Model 271021 mean yang didapatkan sebesar $65 \mathrm{ml}$. Mean pada RPM 5600 dengan menggunakan Alat uji injektor berbasis mikrokontroler adalah $\mathbf{6 0} \mathbf{~ m l}$ sedangkan dengan RPM sama pada alat Model 271021 mean yang didapatkan sebesar 59 ml. Selanjutnya pada tingkat keseragaman yang terdapat pada Alat uji injektor berbasis mikrokontroler dengan mencari persentase keseragamannya injektor 1 dan injektor 2 pada RPM 750 didapatkan hasil 0\%, RPM 3200 didapatkan 0\% dan RPM 5600 didapatkan 0\%. Model 271021 dengan mencari persentase juga dengan injektor 1 dan 2 pada RPM 750 didapatkan hasil 0\%, RPM 3200 didapatkan 0\% dan RPM 5600 didapatkan $\mathbf{0 \%}$. Untuk lebih jelasnya dapat kita lihat pada grafik gambar 7.

\section{SIMPULAN}

Berdasarkan hasil pengujian dan analisa diatas dapat disimpulkan bahwa alat uji injektor berbasis mikrokontroler mampu melayani pembersihan injektor, pengetesan sudut penyemprotan, volume penyemprotan, dan keseragaman penyemprotan sehingga dapat dijadikan alat uji injektor dan pembersihan injektor.

\section{DAFTAR RUJUKAN}

[1] Hidayat Rahmat, Perawatan Injektor Pada Sistim Elektronic Fuel Injektion Bahan Bakar Mobil Avanza di Agung Toyota Muara Bungo, Padang, 2016.

[2] Ruswid, "Electronic Fuel Injection," Sirampog, 2008.

[3] Maksum Hasan, dkk."Teknologi Motor Bakar"padang: UNP Press,2012.

[4] Toyota, Step 2 Elektronik Fuel Injektion, Jakarta: PT. Toyota Astra Motor, 1997

[5] Toyota, Materi Pelajaran Engine Gruop New Step 1, Jakarta: PT Toyota Astra Motor, 1972

[6] Pranoto Aji Dkk, "Analisa Kerusakan dan Model Perawatan Injektor pada Sistem injeksi Bahan Bakar elektronik," Teknologi, vol. 7, no. 2, pp. 175-178, 2014.

[7] Hidayat Rahmat, "Rancang Bangun Alat Uji injektor Berbasis Mikrokontroler," Universitas Negeri Padang, Padang, 2018.

[8] Sugiyono, Metode Penelitian Kuantitatif, Kualitatif, dan R\&D. Bandung: Alfabeta,2015.

[9] Sudijono Anas, Pengantar Statistik Pendidikan. Jakarta: PT Raja Grafindo Persada,2003.

[10] A. N. Miftachul and B. Waluyo, "Model Sistem Monitoring Minyak Pelumas Digital Dengan Memanfaatkan Gaya Apung Dengan Sensor Load Cell”, $A E$, vol. 1, no. 01, pp. 24-29, Apr. 2018.

[11] H. Fahrian, S. Munahar, and D. S. Putra, "Pengembangan Sirkuit Security System untuk Meningkatkan Driver Behaviour Control pada Kendaraan”, $A E$, vol. 1, no. 01, pp. 13-19, Apr. 2018.

\section{Biodata Penulis}

Rahmat Hidayat, S.Pd. Menyelesaikan studi S1 Teknik Otomotif UNP dan saat ini sedang melanjutkan studi PPG di Universitas negeri Yogyakarta.

Dwi Sudarno Putra, S.T., M.T. salah satu pengajar di Jurusan Teknik Otomotif Universitas Negeri Padang. Mendapatkan gelar Master dari Universitas Indonesia, dan sebelumnya pernah menyelesaikan gelar sarjana S1 di Universitas Gadjah Mada. Dengan minat penelitian di bidang ototronik. 
Irma Yulia Basri, S.Pd., M.Eng. merupakan dosen Jurusan Teknik Otomotif FT UNP, dengan latar Pendidikan S1 Pendidikan Teknik Elektronika FTUNP, S2 Teknik Elektro UGM.Saat ini mengajar pada mata kuliah Sensor dan Transduser, Listrik dan Elektronika dan autoCAD. 